\title{
NATIONAL WATER SUMMARY PROGRAM
}

\section{BACKGROUND}

Recent concerns about impending water crises related to quantity and/or quality of water have increased public interest in the condition of the Nation's water resources. Although the country must deal with a number of serious regional and local water-quality and water-supply issues, the Nation as a whole is not running out of water. The long-term or renewable supply of water in streams and aquifers of the 48 conterminous States is about 1.4 trillion gallons per day. That is more than 3 times the present daily rate of freshwater withdrawals in the Nation and about 14 times the rate of consumptive use of water (water that is not available for immediate reuse). These facts in themselves, however, do not guarantee that adequate water supplies of an acceptable quality will be available when and where needed.

Periodic analysis of national water conditions and the identification of water issues have long been recognized as points of departure in evaluating the effectiveness of water programs and in formulating water-policy options. The Congress, for example, has mandated that a number of Federal agencies periodically examine their naturalresources policies and programs in the context of changing resource conditions. These analyses depend upon information about the condition of water resources and the changes that occur as water supplies are developed and used. The U.S. Geological Survey established the National Water Summary Program to help organize such water information for use by those who prepare water assessments and to increase public understanding of the nature, geographic distribution, magnitude, and trends of the Nation's water resources.

\section{GOALS AND OBJECTIVES}

The overall goal of the National Water Summary Program is to keep the Congress, Federal, State, and local officials, resource managers, and the general public informed about changes and trends in the availability, quantity, quality, and use of water resources and to present water information in ways that aid the analysis and develop- ment of water policies, legislation, and management actions. Specific program objectives are to (1) describe the geographic extent and magnitude of water issues; (2) develop and maintain maps and national summary statistics that support the quantification of water issues and the description of water conditions; (3) improve methods to evaluate and characterize the effects of land and water uses on the distribution and availability of water resources; and (4) portray the challenges and opportunities associated with managing water resources.

\section{ACTIVITIES}

Activities of the National Water Summary Program designed to achieve the Program's goals include:

- Publication of National Water Summary reports that describe water conditions and provide overviews of specific water issues;

- Preparation of special publications that provide a national overview of some aspect of water resources, such as a map showing the average runoff in the United States;

- Identification of water issues;

- Development and maintenance of water-resources summary statistics that support the identification of water issues and the characterization of current water conditions and trends; and

- Research on methods to the characterization of water resources conditions, trends, and variability.

Information gathered by a number of Geological Survey programs, such as the National Stream-Quality Accounting Network (NASQAN), the Regional-Aquifer Systems Analysis (RASA) Program, the National Water-Use Information Program, and the Toxic Waste-Ground-Water Contamination Program, coupled with the results of hydrologic investigations conducted by the Geological Survey in cooperation with more than 900 State and local agencies, provide the basis for a continuing description of the national water situation and the identification of water issues. Waterresources information collected by State agencies and other Federal agencies also is used in preparing National Water Summary reports. 


\section{PRODUCTS}

Products of the National Water Summary Program reflect the changing needs of various groups for water information. The results and illustrations in these reports are widely used in the water assessments and policy documents of other organizations.

A major product of the National Water Summary Program is the National Water Summary annual report. As of 1988 , four reports in this series have been published:

- National Water Summary 1983-Hydrologic Events and Issues (USGS Water-Supply Paper 2250);

- National Water Summary 1984-Hydrologic Events, Selected Water-Quality Trends, and Ground-Water Resources (USGS Water-Supply Paper 2275);

- National Water Summary 1985-Hydrologic Events and Surface-Water Resources (USGS Water-Supply 2300); and

- National Water Summary 1986-Hydrologic Events and Ground-Water Quality (USGS Water-Supply 2325).

Each report contains a chronology of hydrologic and water-related events for the water year, a hydrologic interpretation of selected water issues, and a State-by-State summary of selected water issues. The first report (1983) documented the variety of water issues that are of concern to the States and that appear to have nationwide significance. Among these issues are:

- Increasing competition for water supplies;

- Vulnerability of surface-water supplies and shallow groundwater supplies to drought;

- Need for improved control of surface-water pollution, especially nonpoint sources of pollution, such as runoff from agricultural and urban areas;

- Prevention of contamination of ground-water supplies and the mitigation of existing sources of ground-water pollution, such as hazardous waste sites; and

- Declining ground-water levels associated with increased use of ground water.

Using these findings, the themes for the 1984, 1985, and 1986 National Water Summary reports were selected. Future National Water Summary reports and related publications will examine other hydrologic issues of national significance.

\section{SELECTED BIBLIOGRAPHY}

Gebert, W.A., Graczyk, D.J., and Krug, W.R., 1987, Average annual runoff in the United States, 1951-80: U.S. Geological Survey Hydrologic Investigations Atlas HA-710.

Graczyk, D.J., Krug, W.R., and Gebert, W.A., 1986, A history of annual streamflows from the 21 water-resources regions in the United States and Puerto Rico, 1951-83: U.S. Geological Survey Open-File Report 86-128, 30 p.
Hitt, K.J., compiler, 1985, Surface-water and related land resources development in the United States and Puerto Rico: U.S. Geological Survey special water-resources map, scale $1: 3,168,000$.

Krug, W.R., Gebert, W.A., and Graczyk, D.J., 1986, Preparation of average annual runoff map of the United States, 195180: U.S. Geological Survey Open-File Report 86-535, 34 p.

Lanfear, K.J., and Schornick,.J.C., Jr., 1985, Digitized hydrologic units for the United States at a scale of 1:2,500,000: U.S. Geological Survey Open-File Report 85-92, 12 p.

Moore, G.K., Batton, L.G., Allord, G.J., and Robinove, C.J., 1983, Application of digital mapping technology to the display of hydrologic information-A proof-of-concept test in the Fox-Wolf River basin, Wisconsin: U.S. Geological Survey Water-Resources Investigations Report 834142, 118 p.

New England River Basins Commission, 1981, Water resources assessments-Principles of design and implementation (Contract report prepared for the U.S. Geological Survey): National Technical Information Service report PB 84-124155.

Petsch, Harold, Jr., 1985, Inventory of interbasin transfers of water in the western conterminous United States: U.S. Geological Survey Open-File Report 85-166, 31 p.

Thomas, H.A., Jr., and others, 1983, Methodology for waterresources assessment (Contract repurt prepared by Harvard University for the U.S. Geclogical Survey): National Technical Information Service report PB 84124163.

Tunstall, D.B., compiler, 1983, Supporting data for Environmental Trends: U.S. Geological Survey Open-File Report 83$534,185 \mathrm{p}$.

U.S. Geological Survey, 1984, National water summary 1983 Hydrologic events and issues: U.S. Geological Survey Water-Supply Paper 2250, 243 p.

U.S. Geological Survey, 1985, National water summary 1984Hydrologic events, selected water-quality trends, and ground-water resources: U.S. Geological Survey WaterSupply Paper 2275, 467 p.

U.S. Geological Survey, 1986, National water summary $1985-$ Hydrologic events and surface-water resources: U.S. Geological Survey Water-Supply Paper 2300, 506 p.

U.S. Geological Survey 1988, National water summary 1986 Hydrologic events and ground-water quality: U.S. Geological Survey Water-Supply Paper 2325, 560 p.

\section{FOR ADDITIONAL INFORMATION}

Further information on the National Water Summary Program and its products can be obtained from:

Chief, Branch of National Water Summary

Office of Assistant Chief Hydrologist for Water Assessment \& Data Coordination

U.S. Geological Survey

407 National Center

Reston, VA 22092

(703) 648-6851; FTS959-6851

Open-File Report 88-713

September 1988

Edith B. Chase 